\title{
Universiteit
}

Leiden

The Netherlands

\section{Anthropology and empire}

Sysling, F.H.; Goss, A.

\section{Citation}

Sysling, F. H. (2021). Anthropology and empire. In A. Goss (Ed.), The Routledge Handbook of Science and Empire (pp. 70-79). London: Routledge. doi:10.4324/9780429273360-7

Version:

License:

Downloaded from: $\quad$ https://hdl.handle.net/1887/3221249
Publisher's Version

Licensed under Article 25fa Copyright Act/Law (Amendment Taverne)

Note: To cite this publication please use the final published version (if applicable). 


\section{7 \\ ANTHROPOLOGY AND EMPIRE}

Fenneke Sysling

\section{The history of anthropology}

There are many places and times to locate the start of anthropology, the study of mankind. In the fifth century в Се, Herodotus wrote about the customs of the nomadic people north of Greece, and four centuries later the historian Sima Qian in China wrote about the neighbouring Xiongnu tribes. Both authors lived in societies that could spare manpower for writing histories (classical Greek city states and the Han dynasty), and they both travelled extensively and grappled with questions about how to explain differences between one's own people and those outside the boundaries of one's own society. ${ }^{1}$

It is no surprise, then, that the history of anthropology is entangled with the history of the explorations of Europeans from the fifteenth century onward, and subsequently became fully intertwined with their fully-fledged empires. The growing importance of systematic study in Enlightenment Europe and the increasing number of encounters with non-Europeans were stimuli for descriptions of what was different (and what was similar) about these people: their bodies, their dress, their customs, their languages, their behaviour, their kinship systems and their norms, values, and beliefs. These descriptions could be pejorative or positive, universalistic or relativistic, and they reflect on Europeans themselves as much as those they described. Together with these descriptions, Europeans also developed ideas about how societies work (or should work), and proposed models of development and progress that they also used to classify those who were outside Europe's fast developments. ${ }^{2}$

It was only in the nineteenth century that the missionary or administrative ethnographies of the earlier period were transformed into the more systematic, modern, and scientific discipline of anthropology, while the balance of power tilted decisively in favour of Europeans. But the fact that anthropology became recognizable as a discipline does not mean that it was uniform. One important difference, for example, was between medically educated anthropologists who focused on biological (i.e. racial) differences and similarities, and others who specialised in cultural traits. Different traditions and theoretical frameworks also developed across Europe-with distinct national traditions of anthropology in Germany, France, and Britain. The four-field approach-integrating physical (biological) anthropology, archaeology, linguistics, and cultural anthropology - propagated by Franz Boas at the start of the twentieth century came to dominate academic anthropology in the United States. Over time, new conceptions of culture 
succeeded one another: evolutionary frameworks were replaced by structuralist theories and later by postmodern theories.

The developments outlined above mean that some heavily "anthropologised" regions of the world have seen different generations of anthropologists come and go. The island of Bali, in today's Indonesia, in particular became a "test case for new methods of research and theoretical approaches in anthropology."3 The Balinese first encountered Europeans when Portuguese and Dutch traders visited their island in the sixteenth century. When Cornelis de Houtman's ships called at the island in 1597, the shore-going party included Aernoudt Lintgensz, who wrote a short note about his visit and his encounter with the local king and the latter's entourage of nobles and deformed individuals. ${ }^{4}$ In 1847, in the course of another Dutch expedition to Java, Madura, and Bali, W.R. van Hoëvell, a Dutch protestant minister, scholar, and later politician, described the Balinese as having "nobler and more symmetrical features" than the neighbouring Javanese. $^{5}$

From the late nineteenth century onwards, once the whole of the Dutch East Indies had come more firmly under Dutch imperial control, many other European scholars followed. Between 1896 and 1898, the islands of Java, Bali, and Lombok were visited, for example, by the German anthropologist Adolf Bastian (1826-1905), a critic of the evolutionism then current in Britain. Bastian thought all cultures had a common origin. He was an avid traveller and brought major collections of ethnographic artefacts back to Germany. In the early twentieth century, "baliology" came of age, partly through work done by Dutch ethnologists who were also part of the colonial government. Due to the work of these Dutch ethnographers, such as Julius Jacobs and J.E. Liefrinck, the island also featured in works with a broader scope, such as The Golden Bough (1906) by the evolutionist anthropologist James George Frazer, who mentions the Balinese in writing about beliefs in demons and rituals surrounding the harvest of rice.

Biological anthropologists too found the island interesting. In the late 1930s, Ernst Rodenwaldt, a German specialist of tropical medicine, anthropologist, and later professor at the pro-Nazi medical school of University of Heidelberg, investigated racial differences between the different Hindu castes in Bali. ${ }^{6}$ In 1938, the Dutch biological anthropologist J.P. Kleiweg de Zwaan also did fieldwork on Bali, measuring the bodily dimensions of the Balinese. He was interested in Bali because it was a place where different racial influences intersected. The fact that the inhabitants of Bali included the Bali-Aga, a non-Hindu people who were believed to have been there for longer than the other Balinese peoples, made the island, in the words of Frie Kleiweg de Zwaan-Vellema, Kleiweg's wife and research assistant, "an exquisite restaurant for anthropologists and ethnologists."

Kleiweg de Zwaan may have encountered Margaret Mead on the island in 1938, where Mead carried out research together with her then husband, the fellow anthropologist Gregory Bateson. Mead represented a different anthropological tradition again. Racial science had been criticised right from the start, and Margaret Mead was one of its most outspoken American critics, exposing the flaws of racial research and thinking. ${ }^{8}$ She was a student of Franz Boas and emphasised culture and personality (and how the former influenced the latter), and the method of observation and visual anthropology. Bali was one of the field sites where this new direction was practised. ${ }^{9}$

Anthropological interest in Bali of course continued after the colonial era ended with Indonesia's independence in 1945. But these political changes also triggered new scholarly directions. From the 1960s, scholars of the postcolonial generation started to engage critically with their discipline's colonial past, perhaps most famously in Talal Asad's 1973 book Anthropology and the Colonial Encounter. ${ }^{10}$ The anthropologists' complicity in the colonial order was severely criticised, and this was tied to criticisms of objectivity and positivism. South 
African sociologist Bernard Magubane, for example, added fuel to the debate in an analysis of studies on social change in Africa, published in 1971, which held that the only contribution of these anthropological works was "their implicit consecration of the hegemony of white colonialists." 11 This debate took off not least thanks to the protests and academic criticism from the newly independent nations and from academics of colour based at universities in the West.

The criticism was aimed especially at British social anthropology, the branch of anthropology that made a lasting impact on the discipline in the first half of the twentieth century with its emphasis on fieldwork, and on the idea that every society was "historically rooted and environmentally conditioned" instead of following a general evolutionary law. Critical engagement received a new impetus in the 1990s, when the criticism was broadened to include more kinds of anthropology, such as evolutionary anthropology or biological anthropology; more kinds of anthropologists, such as missionary ethnographers; and a wider variety of locations.

These generations of postcolonial critics have laid bare the various entanglements between anthropology and empire, highlighting several aspects or levels of the relation between the two, which we will trace in the following pages. First, anthropologists found practical support in the empires and their infrastructure. Second, they produced knowledge that was then applied by administrators, thus providing fuel for colonial governance. Third, even if the knowledge anthropologists produced was not directly useful, anthropological work still supported the empire as an ideology, and the empire was equally an ideological driving force for anthropologists. Fourth, this also meant that the anthropologists' work was flawed, because they did not do justice to the people they described and failed to see the impact of colonialism on their daily lives.

\section{Practical entanglements}

Colonialism afforded opportunities for anthropologists to travel to and in colonial territories, to network with missionaries and administrators already there, and to live among communities for shorter or longer periods. They were also dependent on official permission, patronage, or material support from colonial institutions. When Thomas Huxley wanted to collect anthropological photographs of as many "tribes" of colonised people as possible for anthropologists to study, he contacted the British Colonial Office in 1869, who sent a notice to their governors asking them to support the project and to send in photographs according to the instructions Huxley had given. Forty sets of images returned to Britain. The French Institut d'Ethnologie at the Sorbonne in Paris, founded in 1925, was funded by taxes collected in the French Empire, which the institute was supposed to serve. ${ }^{12}$

For anthropologists, there was usually some colonial paperwork involved in travelling to and through colonies. They, like other scientists, needed letters of support from colonial governors before they were allowed in. Though French anthropologists often studied French colonial subjects, and so on, there was not always such a neat national division. German and Swiss anthropologists, for example, were also welcome in the Dutch Indies or British India. When the Dutch anthropologist J.P. Kleiweg de Zwaan paid a visit to the governor-general of the Dutch East Indies, he was given permission to do fieldwork on the island of Nias but was warned not to collect skulls, because the government feared the same unrest as was caused by his Italian counterpart Elio Modigliani when he visited the island.

Long periods of fieldwork were a new and defining feature of social anthropology in the early twentieth century. This brought interaction and increasing closeness with research subjects, with the anthropologists the only ones who could move out whenever they wanted to. Paradoxically, although these fieldwork specialists needed the infrastructure of Empire, 
anthropologists preferred to study people they thought were not yet corrupted by modernity and colonialism. George Stocking, a historian of anthropology, refers to the view of the nineteenth-century anthropologist William Rivers that "the most favourable moment for anthropological work" was about 10-30 years after a people had been brought under the "mollifying influences of the official and the missionary": long enough to be able to count on a "friendly reception and peaceful surroundings" but "not long enough to have allowed any serious impairment of the native culture."13

Biological anthropologists had different needs than cultural or social anthropologists. Biological anthropology, the branch of anthropology concerned with the biological or racial characteristics of humans, was based on measurements of bodily dimensions: either of skeletons (usually carried out in Europe), or of living human beings. This was seen as a good "firstcontact science," as the only communication it required was to persuade people to be measured, and these measurements could be done in days or weeks. When empire came to Europe, in the form of visits by non-Europeans - as part of expositions known as "human zoos," for example-biological anthropologists would take the opportunity to do measurements there, whereas for social anthropologists there was little to gain from these events.

Many anthropologists criticised the colonial project because they saw the impact of colonialism on the subjects they studied, even though at the same time they themselves were pushing the boundaries of empire. Their fear of cultural and actual decline could be motivated by humanitarian concerns, but also by selfish ones. However, as Wendy James writes,

[a]s an individual, the anthropologist can often appear as a critic of colonial policy $\ldots$ and he was usually at odds with the various administrators, missionaries and other Europeans he had dealings with ... [but] in the inter-war period at least, open political dissent was scarcely possible within colonial society. ${ }^{14}$

\section{Useful knowledge for the empire}

Early anthropologists, not unlike many of us today, often justified their projects by insisting (or exaggerating) that their knowledge was useful for, and encouraged by, the state. One of the ways in which empire and anthropology were intertwined was a result of anthropologists arguing that their expertise could be directly applied to colonial governance. And in turn, colonial officials accepted that anthropology, social anthropology especially, was producing useful knowledge. As Helen Lackner noted about Nigeria:

Functionalist theory in social anthropology is the type of analysis of colonial communities that answers best the questions asked by the ideologues of Indirect Rule. The studies of Ibo social structure helped the administration by providing it with valuable information about institutions that it needed to understand: what chiefs were there and how much and what kind of power did they have? How institutionalized and how close-knit were the women's organizations? ${ }^{15}$

Another of those questions was "who owns the land"? In Fiji, for example, as critics of anthropology have shown, anthropologists influenced colonial (and postcolonial) structures of land tenure. They singled out one of Fiji's social structures, mataqali, as the group that could register land, while in fact there was not just one system, and other groups such as families could own land too. This colonial production of knowledge was appropriated by Fijians themselves, who used it in postcolonial times to exclude Indian migrants from buying land. ${ }^{16}$ 
On Bali in the Dutch East Indies, as Henk Schulte Nordholt has shown, ethnographers provided colonial bureaucrats with a model of Balinese society and Hinduism that then became rooted and cemented in the bureaucratic regime. The regime thus imposed caste structures that had been more flexible and variable in the past, and used them, for example, to define who had to do forced labour. The lower castes had to do forced labour as colonial "corvée," while the higher casts were exempt. Corvée labour then became the defining marker of difference between casts. One result was that there was also a run on noble titles. This was an invented tradition of a rigid caste system. ${ }^{17}$

In the Italian colony of Eritrea, Alberto Pollera was a colonial judge and one of the few Italian colonial ethnographers; his ethnographical knowledge, as Barbara Sorgoni writes, clearly influenced his administrative practice. Pollera's ethnographic work persuaded him that the "straight adoption of Italian justice and penal sanctions could not fit with radically different customs." When he was confronted with the case of the ritual killing of an enemy by young Kunama men, Pollera manipulated what he perceived to be an Indigenous tradition to serve his colonial needs. In 1909 he developed and introduced a traditional oath that the local Kunama chiefs had to swear at a sacred stone, by which they promised not to kill any more. ${ }^{18}$

\section{Knowledge as ideology}

A lot of knowledge that was produced however-by social anthropologists of the interwar period, or by others such as evolutionary anthropologists or biological anthropologists-was not directly useful in practice. Although anthropologists usually suggested that what they did was useful for colonial governance, officials often felt that much of anthropologists' work did not relate much to their daily administrative problems. Talal Asad for example agreed that most anthropological knowledge was "trivial" or "too esoteric for government use."19

That does not mean, however, that this knowledge production was entirely divorced from the larger imperial project. At the core of anthropology as a science lay the endeavour to define and explain the differences between European people and those outside Europe; and by defining who was civilised and who was not, it provided a mental framework to justify the larger project of empire, and sketched possible pathways of extinction or slow progress under European guidance. As Archie Mafeje has pointed out: "The intellectual effort was a service to colonialism not because of crude suppositions about direct conspiracy or collusion but because of the ontology of its thought categories." ${ }^{20}$

Critics of anthropology have argued that even the gathering of data already legitimised the subordination of the subject. As Diane Lewis stressed in 1973, the relation between the anthropologist and his or her subjects was dangerously close to that of the coloniser and colonised: "The anthropologist, like the other Europeans in a colony, occupied a position of economic, political, and psychological superiority vis-à-vis the subject people." ${ }^{21}$ Even if administrators found the anthropologists' work irrelevant, and vice versa, both groups still worked within a framework in which they were on the same side; in working to understand and improve those on the other side, they shaped these roles and strengthened each other's legitimation in the process.

If this was true for social anthropology, it was perhaps even truer for the more sweeping evolutionary approach in which anthropologists attempted to identify stages and laws of human (or cultural) evolution. It was also true for biological anthropology, which had "race" as its central object of study. Emmanuelle Sibeud argued in 2012 that French physical anthropology was a "useless" colonial science. Especially considering the investments it took to do the "tedious, seemingly endless, and hardly rewarding task of collecting bones or measuring reluctant Natives" and to define racial differences, French anthropologists were at a loss to produce useful 
theories and support for the French Empire. ${ }^{22}$ Their research, according to Sibeud, blurred colonial categories rather than offering practical support for colonial policies. But even if we accept Sibeud's arguments about anthropology's lack of usefulness to the colonial state, physical anthropologists propagated the idea that race was a valid category and thus provided an intellectual foundation for colonial, segregationist policies and practices.

\section{Anthropological work and research subjects' lives}

Even though anthropological work did not have to be relevant or even accurate to support the colonial power structures, this was still a mutually constitutive process, according to critics such as Asad. In his view, "the fact of European power, as discourse and practice, was always part of the reality anthropologists sought to understand, and of the way they sought to understand it." ${ }^{23}$ This entanglement of anthropologists with the empire and with the larger imperialist mindset also influenced the theoretical choices anthropologists made, and meant, according to critics, that anthropologists did not do justice to their research subjects' lives.

The elements of anthropological theorising that received the most criticism were the ways in which anthropologists associated their research subjects with the past and with earlier evolutionary stages, thus defining them as primitive people or as noble savages. ${ }^{24}$ Anthropologists also constructed and cemented categories such as "race" and "tribe," and ignored the role the changes of European colonialism played in people's lives. ${ }^{25}$ As Catherine Gough argued in a provocative piece in 1968: "We have virtually failed to study Western imperialism as a social system, or even adequately to explore the effects of imperialism on the societies we studied." 26

For the history of Africa such failures meant that African structures were often described without taking into account the fact that local chiefs fell under European power and ultimately depended on that. Talal Asad describes the work of the anthropologist Meyer Fortes, for example, who worked among the Tallensi in modern Ghana: In his book about the Tallensi, Fortes hardly mentioned British rule, despite having noted earlier that "the political and legal behaviour of the Tallensi ... is as strongly conditioned by the ever-felt presence of the District Commissioner as by their own traditions." 27

This approach disguised the impact of the colonial presence in the life of locals, and continued the portrayal of non-Europeans as if they were living in a timeless past. And if anthropologists did write about change, about urbanisation for example, they found it hard to explain why people still held on to ideas and practices that did not seem to fit with their place in the modern world and which were then depicted as “ 'myths' that help people cope with disorientation or resist oppression." ${ }^{28}$ The anthropologists' method and analysis, Magubane's verdict ran, "has provided ideological blinders as to the true condition of urban Africans." ${ }^{29}$

\section{Recent generations of scholars}

Since the turn of the millennium, a new generation of historians of anthropology have presented themselves as moving away from the earlier critics. They position themselves as less inclined to portray colonialism as a "totalising project" and anthropology as its ally in that project. Instead, they stress the agency of non-Europeans, the limitations and ambiguities of colonial power, and the anxieties of the colonial officers. Hesitant, vulnerable, messy, and contradictory are the keywords here (although it must be admitted that many of the earlier generation were also quite open to nuance and ambiguity). The new generation have also started to look at more localities, more forms of colonial power, and more kinds of producers, users, and brokers of knowledge, from professional anthropologists to missionaries, and from local teachers to traditional healers. 
Lyn Schumaker, for example, writes that "looking at anthropologists' relationships with particular colonial projects rather than evoking the dominant influence of a hegemonic and homogeneous colonialism promises a more productive approach." ${ }^{30}$ Helen Tilley suggests that "it seems fair to say that anthropology's significance to colonial regimes was usually much less than that of other fields, such as the environmental or medical sciences." But anthropology was still "deeply imbricated in imperial affairs." ${ }^{11}$ For Germany, H. Glenn Penny and Matti Bunzl argued that German anthropology was "tightly bound up in a range of intellectual traditions that were much richer and more multifarious than a simple colonialist drive." These traditions did not easily change once Germany became a colonial nation, or again when it lost its colonies, and German anthropologists maintained a very wide geographical interest, with many studies of Brazil for example. ${ }^{32}$

This new generation have also presented case studies that show that anthropologists were not always in line with the colonial discourse, and sometimes used their careers and anthropological tools to criticise the system from within. Alice Conklin writes that the experience of intensive field work in the French Empire in the early twentieth century "relativized younger ethnologists' understanding of race and culture." As a result they analysed the "ravages of Empire" in their works and challenged older ideas about race. ${ }^{33}$ Similarly, American biological anthropologists such as Harry L. Shapiro started to doubt the value of race when they arrived in Hawai'i for fieldwork in the 1920s and 1930s. ${ }^{34}$ Germany in some sense showed the opposite of English and French development, with its liberal stance in the nineteenth century but increasingly nationalist and racist tradition in the twentieth.

The attempt to avoid a binary anthropologist-versus-object relation also meant that this new generation paid more attention to the different roles of colonised people in the shaping of knowledge. Both coloniser and colonised were affected by the encounter, writes John MacKenzie, and they were "always interactive in some shape or form." 35 Colonised people gathered and supplied data, for example, or acted as Indigenous translators, or themselves became anthropologists who incorporated some aspects of Western anthropological thinking and dismissed others. Some of the Indigenous authors were very critical of Western categories; others used an idiom that "resonated with their patrons' existing assumptions." 36 Omnia El Shakry, for example, showed that the anthropological tradition in Egypt, already vibrant under colonialism, sought to demonstrate "the uniqueness of the Egyptian culture, race, and history." The Egyptian nationalist intelligentsia resisted the totalising European claims and developed an alternative, but also incorporated Western ideas such as an emphasis on the moral uplifting of the masses, and an Indigenous discourse on race. ${ }^{37}$

In French West Africa, West Africans have been writing ethnographical texts since the 1920s. These men were often schoolmasters who had received Western education and worked for a certain period as assistants to European anthropologists, who did not like them to go beyond simple anthropological reporting. As J-H. Jezequel describes, Mamby Sidibé, a schoolmaster and ethnographer, wrote a study in 1923 about the Banfora region (Upper Volta); this study "protested against colonial clichés" while also criticising Indigenous societies. ${ }^{38}$ While some of these texts found their way into European publications, others had a local impact of their own, to strengthen local dynasties for example and to reinvent local history.

This new generation of scholars have also turned the focus back on Europe to show how, through museums, anthropology was connected to a mass culture in Europe. This work takes the museum, and the histories and trajectories of its objects, seriously as research subjects. Through a focus on the collecting, ordering, and display of objects such as boomerangs, skulls, or what used to be known as "primitive" or "tribal" art, it shows how museums were important places of anthropological knowledge making and colonial governance. ${ }^{39}$ 


\section{Decolonising anthropology}

The critique on the historical relationship between anthropology and empire has produced shelves full of books and articles, but for many the process has not gone far enough. The independence of former colonies did not make an end to unequal power relations, and many of the categories once produced were not discarded with independence. Museum categories, vocabulary, and shelving practices, for example, are hard to change, so older anthropological ideas have lingered in museums, still shaping ideas about non-Europeans. On the other hand, nonEuropeans have used anthropological works to insist on their indigeneity, and to decide which cultural forms are authentic and which ones are not. Melanesians, for example, have used the concept of "Melanesia" — once a racial ethnographer's term that had no local equivalent-as an empowering concept. ${ }^{40}$ On the island of Bali too, according to Schulte Nordholt, colonial bureaucratic knowledge was reproduced by Balinese intellectuals. ${ }^{41}$

It is not for academics to decide which cultural forms and beliefs people should keep and which they should discard, but even within academia it is not as easy as it seems to fully expunge the colonial mindset. Today's anthropology is still shaped by these relations, and by the work of earlier giants. So how can we get the empire out of anthropology? Every generation of students will encounter new versions of this discussion and will need to be taught how not to copy colonial discourse, how to critically address the categories anthropologists use, and how to assess their own position in the system and their responsibility towards others. Awareness of the past's influence on the present and this continuing discussion has made anthropology one of the most self-reflexive disciplines in academia, from which other disciplines once involved in colonial projects have much to learn.

\section{Notes}

1 Siep Stuurman, "Herodotus and Sima Qian: History and the Anthropological Turn in Ancient Greece and Han China," Journal of World History 19, no. 1 (2008): 1-40.

2 Thomas Hylland Eriksen and Finn Sivert Nielsen, A History of Anthropology (London: Pluto Press, 2001).

3 T.A. Reuter, Custodians of the Sacred Mountains. Culture and Society in the Highlands of Bali (Honolulu: University of Hawai'i Press, 2002), 1.

4 A. Lintgensz and P.A. Leupe, "Bali 1597," Bijdragen tot de Taal-, Land- en Volkenkunde van NederlandschIndië 5 (1856): 203-34.

5 W.R. van Hoëvell, Reis over Java, Madura en Bali, in het midden van 1847, part 3 (Amsterdam: Van Kampen, 1854), 22.

6 E. Rodenwaldt, "Die nicht gemeinsamen Rasseelemente der Balischen Kasten," Archiv für Rassen- und Gesellschaftsbiologie 32 (1938): 111-42.

7 Notes by Mrs. Kleiweg de Zwaan-Vellema, n.d. [after 1945], 3, Kleiweg de Zwaan Family private archive, The Netherlands.

8 Margaret Mead, “The Methodology of Racial Testing: Its Significance for Sociology," American Journal of Sociology 31, no. 5 (1926): 465-8.

9 Ira Jacknis, "Margaret Mead and Gregory Bateson in Bali: Their Use of Photography and Film," Cultural Anthropology 3, no. 2 (1988): 160-77.

10 Talal Asad, ed., Anthropology and the Colonial Encounter (Atlantic Highlands, NJ: Humanities Press, 1973).

11 Bernard Magubane, "A Critical Look at Indices Used in the Study of Social Change in Colonial Africa," Current Anthropology 12, no. 4/5 (1971): 419-45, here p. 427. See also Archie Mafeje, "The Problem of Anthropology in Historical Perspective: An Inquiry into the Growth of the Social Sciences," Canadian Journal of African Studies/La Revue Canadienne des études Africaines 10, no. 2 (1976): 307-33.

12 Alice Conklin, In the Museum of Man: Race, Anthropology, and Empire in France, 1850-1950 (Ithaca, NY: Cornell University Press, 2013). 
13 W.H.R. Rivers, "Report on Anthropological Research outside America," in Reports upon the Present Condition and Future Needs of the Science of Anthropology, ed. W.H.R. Rivers, A.E. Jenks, and S.G. Morley (Carnegie Institution of Washington, 1913), 5-28, here p. 7, quoted by George W. Stocking, Jr., "Maclay, Kubary, Malinowski: Archetypes from the Dreamtime of Anthropology," in Colonial Situations: Essays on the Contextualization of Ethnographic Knowledge, ed. G.W. Stocking (Madison: University of Wisconsin Press, 1991), 9-74, here p. 10.

14 Wendy James, "The Anthropologist as Reluctant Imperialist," in Asad, Anthropology and the Colonial Encounter, 41-69, here p. 42.

15 Helen Lackner, "Social Anthropology and Indirect Rule. The Colonial Administration and Anthropology in Eastern Nigeria: 1920-1940," in Asad, Anthropology and the Colonial Encounter, 123-51.

16 John Clammer, "Colonialism and the Perception of Tradition," in Asad, Anthropology and the Colonial Encounter, 199-220; Adrian Tanner, "On Understanding Too Quickly: Colonial and Postcolonial Misrepresentation of Indigenous Fijian Land Tenure,” Human Organization 66, 1 (2007): 69-77.

17 Henk Schulte Nordholt, "The Making of Traditional Bali: Colonial Ethnography and Bureaucratic Reproduction," History and Anthropology 8, no. 1-4 (1994): 89-127.

18 Barbara Sorgoni, "The Scripts of Alberto Pollera, an Italian Officer in Colonial Eritrea: Administration, Ethnography and Gender," in Ordering Africa: Anthropology, European Imperialism and the Politics of Knowledge, ed. Helen Tilley with Robert Gordon (Manchester: Manchester University Press, 2010), 285-308, here p. 290.

19 Talal Asad, "Afterword: From the History of Colonial Anthropology to the Anthropology of Western Hegemony," in Stocking, Colonial Situations, 314-324, here p. 315.

20 Mafeje, "The Problem of Anthropology," 318.

21 Diane Lewis, “Anthropology and Colonialism," Current Anthropology 14, no. 5 (1973): 581-602, here p. 582.

22 Emmanuelle Sibeud, "A Useless Colonial Science? Practicing Anthropology in the French Colonial Empire, circa 1880-1960,” Current Anthropology 53, no. S5 (April 2012): S83-94, here p. S84.

23 Asad, "Afterword," 315.

24 Johannes Fabian, Time and the Other: How Anthropology Makes its Object (New York: Columbia University Press, 1983).

25 Archie Mafeje, "The Ideology of 'Tribalism," The Journal of Modern African Studies 9, no. 2 (1971): 25361; Terence Ranger, "The Invention of Tradition in Colonial Africa”, in The Invention of Tradition, ed. Eric Hobsbawm and Terence Ranger (Cambridge: Cambridge University Press, 1983).

26 Catherine Gough, "Anthropology and Imperialism," Monthly Review 19, no. 11 (1968): 12-27, here p. 19.

27 Talal Asad, "Two European Images of Non-European Rule Compared," in Asad, Anthropology and the Colonial Encounter, 103-118, here p. 108.

28 Asad, "Afterword," 317.

29 Magubane, “A Critical Look,” 427.

30 Lyn Schumaker, Africanizing Anthropology: Fieldwork, Networks, and the Making of Cultural Knowledge in Central Africa (Durham, NC: Duke University Press, 2001), 7.

31 Helen Tilley, "Introduction: Africa, Imperialism, and Anthropology," in Tilley and Gordon, Ordering Africa, 1-45, here p. 6.

32 H. Glenn Penny and Matti Bunzl, "Introduction," in Worldly Provincialism: German Anthropology in the Age of Empire, ed. H. Glenn Penny and Matti Bunzl (Ann Arbor: University of Michigan Press, 2003), 1-29, here p. 7.

33 Conklin, In the Museum of Man, 4.

34 Warwick Anderson, "Racial Hybridity, Physical Anthropology, and Human Biology in the Colonial Laboratories of the United States," Current Anthropology 53, no. S5 (2012): 95-S107.

35 John MacKenzie, “General Editor's Introduction,” in Tilley and Gordon, Ordering Africa, xiii.

36 Tilley, "Introduction: Africa, Imperialism, and Anthropology," 18.

37 Omnia El Shakry, The Great Social Laboratory: Subjects of Knowledge in Colonial and Postcolonial Egypt (Stanford, CA: Stanford University Press, 2007).

$38 \mathrm{~J}-\mathrm{H}$. Jezequel, "Voices of their Own? African Participation in the Production of Colonial Knowledge in French West Africa, 1910-1950," in Tilley and Gordon, Ordering Africa, 145-72, here p. 154. 


\section{Anthropology and empire}

39 Andrew Zimmerman, Anthropology and Antihumanism in Imperial Germany (Chicago: University of Chicago Press, 2001), esp. 240-2; Ricardo Roque, Headhunting and Colonialism: Anthropology and the Circulation of Human Skulls in the Portuguese Empire, 1870-1930 (Basingstoke: Palgrave Macmillan, 2010); Fenneke Sysling, Racial Science and Human Diversity in Colonial Indonesia (Singapore: NUS Press, 2016); Tony Bennett, Fiona Cameron et al., ed., Collecting, Ordering, Governing. Anthropology, Museums and Liberal Government (Durham, NC: Duke University Press, 2017).

40 Melanie Lawson, “'Melanesia,' The History and Politics of an Idea,” The Journal of Pacific History 48, no. 1 (2013): 1-22.

41 Schulte Nordholt, "The Making of Traditional Bali," 90. 